\title{
A Bohemian Wife: The Life and Death of Olga Penton
}

\author{
Patrick Buckridge
}

Olga Penton died of heart failure at her home in Sydney one evening in 1973. She was found the next morning sitting upright in an armchair, with a plate of cold chicken half-eaten on her lap, a knowing smile on her face, and looking a lot younger than her 76 years. This is an image that captures the cheerful stoicism of her last twenty years of life. Fifty years earlier, another sedentary image captures an earlier self: the image is of Olga sitting naked in a bath, presiding over an intellectual salon of writers and free-thinkers in the Brisbane flat she was sharing with her new husband, Brian Penton. It is hard to be sure whether this second image exactly corresponds to reality - neither of my informants was personally present at any of the bathroom salons, and both reported them as a spicy rumour rather than an observed fact - but whether true or not, we can say that the rumour expresses the ambience of intellectual sophistication and sexual daring that seems to have surrounded her at the time. ${ }^{1}$

What I wish to do in this paper is to say enough about Olga Penton's early life to convey some sense of the kind of person she was, and also of the kinds of openings and obstacles to cultural self-expression she encountered in Brisbane when she was living and working here in the early 1920s. I think of her as a 'bohemian' figure (though not in any very strict sense), partly because she thought and spoke of herself that way, and partly to suggest a comparison with women like Bee Miles, Dulcie Deamer and Anna Brennan in Sydney in this same decade, of whom I shall say more in a moment.

Olga Grace Moss was born in the township of Maryland in northern New South Wales in 1897, the second youngest in a family of ten children belonging to the local schoolmaster, George Moss, and his wife, Caroline. George Moss, originally Moses, entered an Anglican seminary as a young man, but after a crisis of faith concerning one of the Thirty-nine Articles he joined the Plymouth Brethren and worked for some years as a missionary teacher in New Zealand and rural New South Wales before meeting and marrying Caroline Bullock in Gulgong. Some time after 1900, George retired from teaching (he was 59 at the time of Olga's 
birth) and the family moved to a grazing property near Stanthorpe, to which they gave the name 'Carraconna'.

George Moss was a religious patriarch of the old school, given to caning his children, boys and girls alike, and to delivering long, public and extempore prayers every morning and night, which members of the family were compelled to attend. In an unfinished memoir written some 50 years later, Olga confessed to a 'thread of real hate for him', and to 'the fear that dominated my whole idea of him. Rage possessed me often ... I despised him for [his] pointless cruelties and prohibitions; ... I learned very quickly to plan defiance, but never overt ... it was always by lying, so that as I grew I became an expert liar ... By the time I was eight I was ... an agile creator of alibis; I had learnt to assume any characteristic to fit his mood and keep him in a good temper.'

This particular form of resistance to authority, by means of masks and alibis, has obvious affinities with the studied artificiality of the 'Decadent' bohemian style of the European fin de siècle, a style that Oscar Wilde memorably defined in his famous essay 'The Decay of Lying', which in turn inspired - not coincidentally, surely - Brian Penton's essay 'A Theory of the Artificial', published in the Queensland University magazine Galmahra in August 1924, some seven months after his marriage to Olga. Penton's essay takes Wilde's paradoxical thesis that 'the decay of lying as an art, a science, and a social pleasure' is one of the chief causes of the 'curiously commonplace character' of modern literature, and extends it to other dimensions of life as well, such as friendship, love and religion, rising to the following grandiose declaration:

No human endeavour reaches so persistently towards the stars, nothing in Art or Science so epitomises the striving which may lift man out of the slime of savagery. Civilisation has no stronger cornerstone than the Artificial. ${ }^{3}$

If, as seems likely, this is as much Olga's voice as Brian's, it suggests a close and conscious connection between her early family conflicts and her style of selfpresentation as a young bohémienne. The early rebellion against her father's rule took other forms as well - secretly reading 'bad books' like Zola's Nana under the bedclothes at night, for example, and using 'bad language' (e.g., 'bugger' and 'bastard') in secret defiance of the thunderbolts her father promised as Divine retribution for such talk. It is interesting to notice how all these forms of rebellion — in reading, speech and personal demeanour - mirror the key gestures of turnof-the-century male bohemianism in Australia, as elsewhere. No doubt Olga's retrospective account, composed some 50 years later, somewhat styled her childhood in these terms; however, the connections seem real nonetheless.

Her dislike of her father notwithstanding, Olga followed him into the teaching profession. She was a brilliant student, with a particular gift (like her father) for the classics, and her older brothers saw to it that she was able to pursue her studies at Rockhampton Girls' Grammar, where she boarded for several years, then stayed on for another year or two as a teacher after matriculating, making the long 


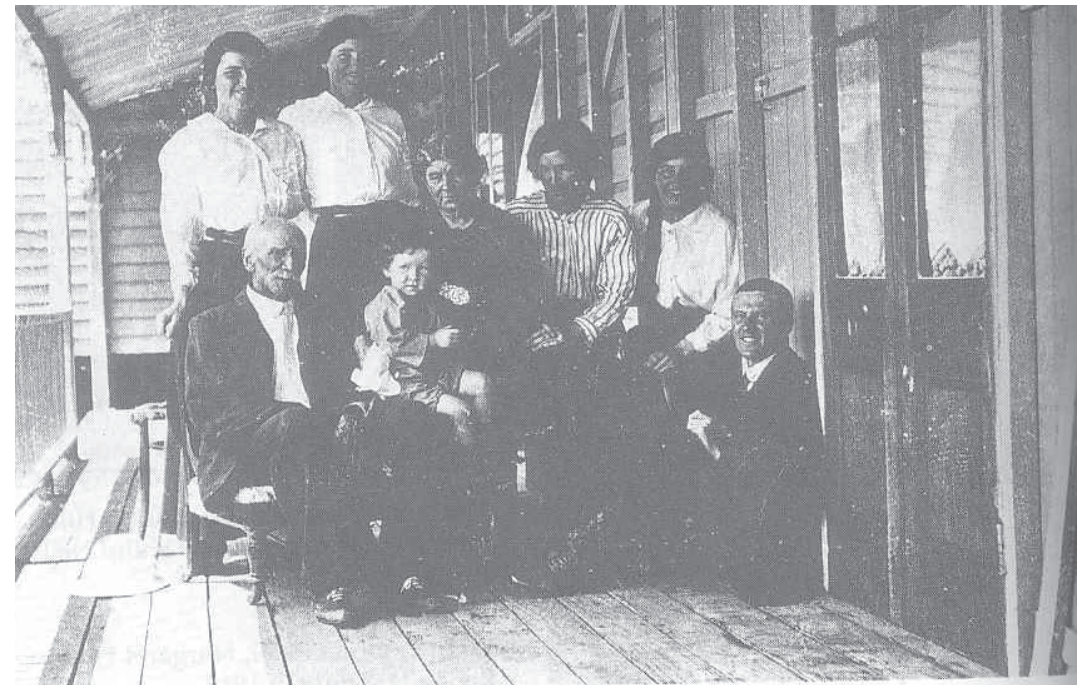

Figure 1: The Moss family, 'Carraconna', c. 1914: George, seated left, Caroline, centre, Margaret, standing left, Olga, seated, second from right

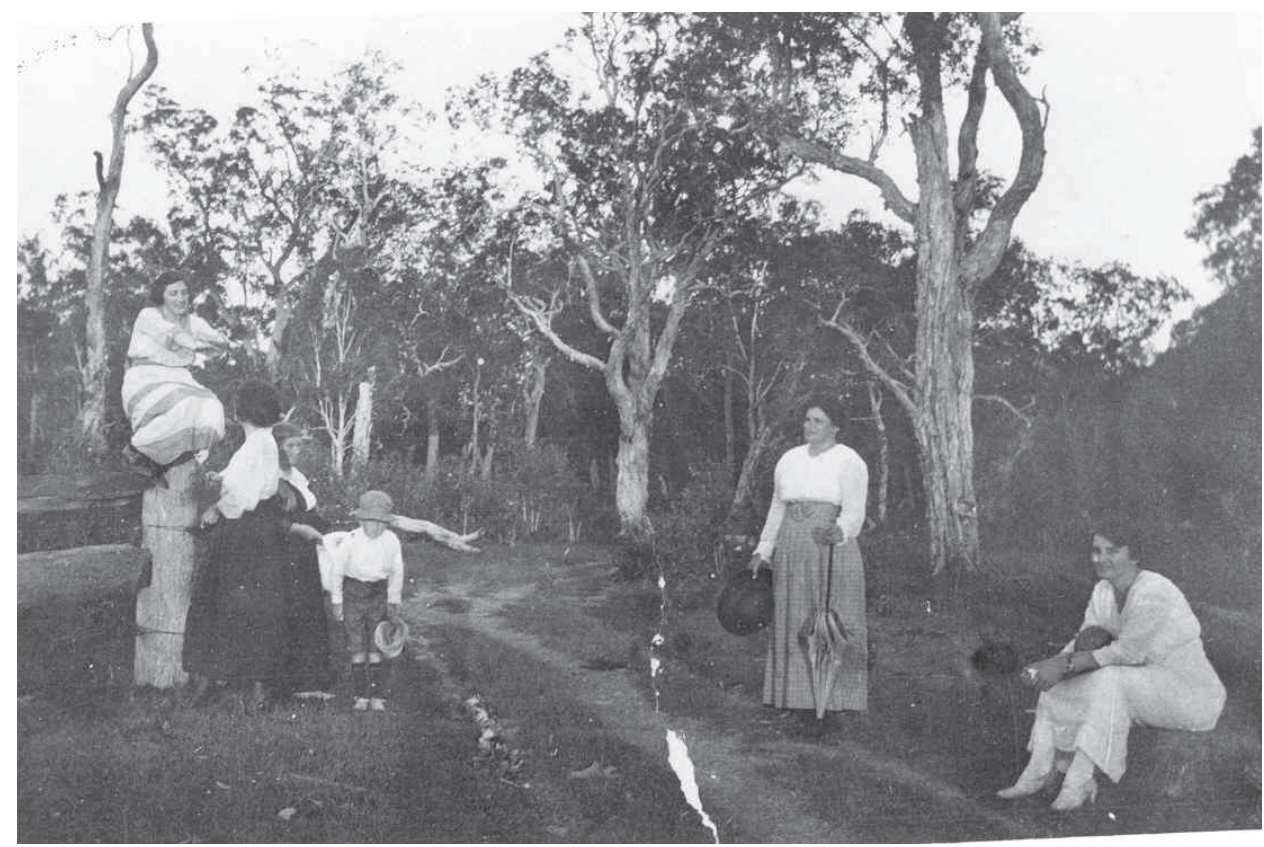

Figure 2: Olga (left) with Moss siblings, 'Carraconna’, c. 1919 
trip home to 'Carraconna' fairly infrequently. In 1916 she spent a year teaching English and Latin at the New England Girls' School in Armidale. ${ }^{4}$ The following year, she enrolled in first-year Latin at the University of Queensland, and spent the next few years in Sydney before turning up in Brisbane again in 1922. Here she found a job at the Brisbane Girls' Grammar School, made some new friends (though not her younger colleague Kathleen Campbell-Brown, who disliked her 'domineering personality'), and within a year had met and married Brian Penton, a reporter with the Brisbane Courier, and some seven years her junior.

Against that background, her own account of their courtship and marriage is perhaps surprisingly romantic and submissive, very much in the 'swept me off my feet' style. Brian, she says in effect, simply would not take 'no' for an answer, and despite her protestations that she could not see the point of it (since neither of them was interested in children), she surrendered to his will. There is some uncertainty about the proposal itself — Penton later claimed that Olga did the proposing - but in either case their relationship seems to have been marked from the beginning by a willingness on her part to accede to his wishes and plans and to preserve (and if necessary reshape) her own ambitions in conformity with his:

On that day was made the blueprint of my life for many years to come - to go with him somewhere and to stay where he put me, waiting for him. That never changed all through our life together: where he left me, there I was to stay till he came back for me or called me on. ${ }^{5}$

Whatever the psychological factors involved in Olga's apparently meek submission - and living first with a tyrannical father, then with a driven, egotistical husband must both have been potent ones - the fact remains that Olga managed to construct and preserve a certain kind of bohemian identity for much of her life, an identity defined more by a 'blue-stocking' intellectualism and fairly liberal views of sexual morality than by any radically subversive social or political views.

How did a woman like Olga Penton fit into Brisbane society in the 1920s? The answer is: not very comfortably. I mentioned earlier the Sydney female bohemians Bee Miles, Dulcie Deamer and Anna Brennan. These women were bohemians of a different, more genuinely subversive sort; their lives posed a more consistent and radical challenge to middle-class social and sexual norms than Olga ever did, and Sydney's 'café bohemia' of the 1920s — so vividly evoked by Peter Kirkpatrick in his book The Seacoast of Bohemia - was a modern urban environment large enough, sophisticated enough and youthful enough to support a vigorous bohemian subculture in which many and varied forms of social deviance and eccentricity could be tolerated and sometimes celebrated. ${ }^{6}$

Brisbane in the 1920s was not like that, and Olga seems not to have felt especially at home in it: she and her ambitious husband were both biding their time until new, more exciting opportunities emerged for them. The city was not, however, quite the 'big country town' evoked in some recent fiction and memoir.7 On the contrary, it seems to have been quite a lively place, if we can judge by 
the number and variety of cultural organisations that were active during these years. Since the late nineteenth century, Brisbane had been fertile ground for the growth of reading, writing, debating and free-thinking societies, and while not all of these had continued on into the 1920s, several of them (like the Johnsonian Club and the Burns Society) had survived, and had been joined since Federation by a host of other cultural organisations: the Brisbane Shakespeare Society, the Dickens Fellowship, the Queensland Authors' and Artists' Association, the Royal Queensland Art Society, the Brisbane Repertory Theatre Society, the WEA, the Lyceum Club, the government radio station 4QG, and organisations representing the German, Polish, French, Greek, Italian and Jewish communities of Brisbane.

All of those listed above were affiliated by the late 1920s with the 'Hall of the Muses', an institution established in George Street in 1927 by Luis Amedeo Pares, a violin teacher and cultural entrepreneur who had arrived in Brisbane from Mareeba four years earlier, organised a concert using 1,300 massed violins in the old Exhibition Building, and commenced publication of a monthly magazine, The Muses' Magazine, which described itself on its masthead as 'A Monthly Review of the Musical, Artistic, Literary and Intellectual Life of Queensland'. It published essays on scientific and cultural subjects, book and theatre reviews, reports on public lectures, and also some poems (often by Mabel Forrest or Emily Bulcock), some original artwork, and a photograph - always the same photograph — of the '1,000 Violins Ensemble’ of August 1927.

I accord this publication some prominence because, even though it lasted for only about two years, it does seem to have gathered up the disparate strands of Brisbane's intellectual, artistic and ethnic culture in a surprisingly catholic and comprehensive way. Like the Hall of the Muses itself, it was neither bohemian nor subversive, and its assumptions and values were very largely those of the high-cultural tradition of Arnoldian liberalism: most of the contributors were academics, doctors, lawyers and scientists, with a sprinkling of practising poets, artists and musicians - cultivated middle-class professionals and their at least equally cultivated wives. At the same time, it featured writing by several interesting and eccentric individuals: Henry Tardent, for example, a Swiss horticulturist and general polymath — and the grandfather of P.R. ('Inky') Stephensen) — was one of its founders and leading lights. Furthermore, its pronounced multiculturalism - each issue featured a page or more of detailed reports by each of the affiliated ethnic organisations - gave it a genuinely international flavour.

The inaugural editorial conveys something of the magazine's heady mix of state and national pride with wider cultural horizons. The Muses'Magazine aspired to be 'the accredited official organ of the intellectual life of Queensland'. 'As a young nation,' Pares wrote,

we claim access to all the civilisations and literatures which have preceded us in the arena of history. Fortunately we have in our midst a great number of men — and women too - who are thoroughly conversant with both the ancient and modern literatures of other lands. A glance at the cover of this Magazine will disclose the fact 
that amongst all the Australian cities Brisbane has the largest number of societies devoted to the study of foreign languages and literatures. Through those societies, young Australians will be able to keep in touch with the intellectual life of other countries as well as our own. ${ }^{8}$

Despite all this, it would probably not have appealed much to the young Olga Penton, or vice versa, though some of her university acquaintances (including Kathleen Campbell-Brown) were peripherally associated with it. Paradoxically, it may have been the very vigour and diversity of Brisbane's 'establishment' cultural networks in the 1920s that failed to provide an especially fertile environment for alternative 'bohemian' formations to flourish. There were, however, some avenues for opposition and subversion.

One publication that was more accommodated to the Pentons' interests and attitudes was the university magazine Galmahra, founded in 1921 by 'Inky' Stephensen, and edited first by him then by a succession of talented young men: Colin Bingham, Cecil Hadgraft and Edgar Holt. It published poems and articles by them and by Jack Lindsay, Brian Penton, Eric Partridge and others. Lindsay and Penton in particular tested the university's tolerance with poems of a frankly erotic cast, and in May 1921 the authorities suppressed the first issue containing a page of Lindsay's poems. A stanza from a poem of Penton's, one of many written for Olga and published in one of the later issues, gives the flavour - and the temperature - of both young men's verses:

Across your breasts the last silk ramparts fall

And crumble in the shadows at your feet.

So swift, so silently you yielded, sweet,

That I could swear you were not clothed at all,

But only left the shadow of the wall.

Your breast against my bed — how little meet -

Like moonlight in a fetid city street

Or prayer and silence in a harlot's hall. ${ }^{9}$

The steamy blend of attraction and revulsion was fairly confronting for Brisbane in the early 1920s, but it seems the university authorities, having made their move against Jack Lindsay two years earlier, allowed Penton's efforts to pass without challenge. Cecil Hadgraft (no doubt as amiable and charming then as he was 40 years later) was the editor in that year, and may well have taken a more conciliatory approach to the university than his more belligerent predecessor P.R. Stephensen. There is some evidence that Penton attempted to distance himself somewhat from the Lindsay legacy at this time. The Fryer Library holds a letter from Penton to Dr F.W. Robinson of the English Department (the legendary 'Doc Robbie'), inviting him to subscribe to a new monthly magazine, The Pagan, which would 'declare an anti-Lindsay cult [and be] the replica of the London Mercury, J.C. Squires' paper'. ${ }^{10}$ Robinson apparently regarded the letter as a calculated insult, refused in no uncertain terms, and spoke subsequently of having 'put Penton in his place'. ${ }^{11}$ 
Brisbane's radical fringe, such as it was, extended some way beyond the university and Galmahra. Jack Lindsay, whose first volume of memoirs deals with his life in Brisbane in the early 1920s, rubbed shoulders with WEA radicals like T.C. Witherby, the odd Russian revolutionary, and American 'Wobblies' like James Quinton. Such connections were more overtly political than Olga was comfortable with. Her 'lifestyle bohemianism' — that of the cocktail party in the bathroom - was influenced less by the politically engaged Jack Lindsay than by his father Norman (with whom she was later good friends), a powerful 'absent presence' in Brisbane in the early 1920s, where his estranged first wife Kate Parkinson and their second son Ray were still living. ${ }^{12}$

Olga's 'alternative' impulses were always more sexually libertarian than politically radical. Indeed, her politics were more consistently conservative throughout her life than Penton's: he at least flirted briefly with communism in his twenties and thirties before hardening into the anti-Labor stance for which he was notorious during and after World War II, when he was editor of the Sydney Daily Telegraph. Olga, by contrast, was repelled by working-class politics, intensely proud of her own rural background (which she and Penton often represented as being considerably older and more aristocratic than it was), and increasingly drawn to Roman Catholicism, to which she became a convert in her later middle age.

Her reputation as a woman of unusually advanced and tolerant views on sex and marriage remained strong, however, and in her relationship with Brian Penton she had much to be tolerant about, as he indulged in a series of openly adulterous affairs throughout the 28 years of their marriage until his death in 1951. The Pentons had what their friends and colleagues called a 'companionate marriage', a term which seems to have meant something closer to 'sexless marriage' than it does today, with the emphasis on each partner's freedom, in principle, to form sexual relationships outside the marriage - a freedom of which they both availed themselves, Olga occasionally, and Penton as a way of life. Her unpublished memoir makes uncomfortably explicit the psychological dynamic of their early relationship, in which her sexual tolerance became (or at least was widely perceived as) a permanent guarantee of complaisance with his infidelities rather than an assertion of her own independence.

What her marital situation does seem to have given her, though - even if it necessitated a certain level of sentimental self-delusion, fed by Penton's private poetic assurances of fidelity 'in the last instance' — was a free space in which to elaborate a carefully stylised persona and to maintain a busy program of cultural and intellectual pursuits largely independent of Brian, who was usually otherwise engaged, and whose journalistic working hours made such activities difficult in any case. The Pentons had moved to Sydney in late 1925, and the Sydney painter Jocelyn Rickards, who met Olga while she was tutoring Rickards' older sister in Latin, described her as 'a self-consciously intellectual woman' who, 'with her black hair pulled tightly back', her 'peasant blouses' and 'multi-coloured dirndl skirts ... looked like a Russell Flint lady crossed with one painted by Norman Lindsay'.13 The similitudes would probably have pleased Olga, who valued her continuing close relationships with Norman and Ray Lindsay especially, and who treasured 
one of Ray's large pen drawings of a Kings Cross cocktail party in which she and many of the Lindsay clan were clearly recognisable. ${ }^{14}$

Of as much interest - at least to the cultural historian - as her personal style and her open marriage are the literary terms in which, in both Brisbane and Sydney, Olga developed and expressed her identity as a bohemian intellectual. She was a voracious reader of European, American and Australian literature, not necessarily of the 'classic' variety, with a particular taste during the 1920s for sophisticated British society novelists like Michael Arlen and Aldous Huxley, satirical fabulists like Anatole France and James Branch Cabell, and the New York City novelists Joseph Hergesheimer and Carl Van Vechten. ${ }^{15}$ Interestingly, none of these novelists, with the exceptions of Huxley and France, is much read or heard of today, but all of them were widely read and reviewed in Australia at the time.

The Red Page of the Sydney Bulletin can provide a useful gauge of public tastes in contemporary British and American literature at the time. During the 1920s, Hergesheimer and Cabell were either reviewed or listed in 'Books Received' a dozen times each, with most of the others not many fewer, and Anatole France (who admittedly died in this decade, giving rise to several obituaries) on no less than 25 occasions. Their greater contemporaries Ernest Hemingway, F. Scott Fitzgerald and James Joyce were each mentioned once in the same decade; Virginia Woolf was mentioned (but not reviewed) four times; and even D.H. Lawrence, who both visited Australia and wrote a novel about it during the decade, rated only ten items. ${ }^{16}$

These names and figures might be interpreted in different ways. For the purpose of understanding Olga's reading as an aspect of her cultural identity, they perhaps suggest a willingness to affirm that identity by reading popular contemporary fiction that nonetheless reflected - as all of these writers did - the cosmopolitanism, sexual sophistication and intellectual self-consciousness she professed in her own life.

James Branch Cabell (1879-1958), whose novels - a series of pseudo-historical, allegorical romances set in the mythological French kingdom of 'Poictesme' - were much admired at the time (though rarely imitated, at least in Australia), nonetheless had a special significance for literary bohemians. In 1920 the publishers of his novel Jurgen had been brought to court by the New York Society for the Suppression of Vice. Cabell had responded by circulating a limited pamphlet titled The Judging of Jurgen, which included a petition of support with most of the literary luminaries of the day as signatories. The case was dismissed in 1922 by a judge who found that the erotic symbolism for which the book was under attack could only be recognised by a very sophisticated reader. ${ }^{17}$

Cabell, then, was something of a short-term cause célèbre at this time for opponents of literary censorship - always a central bohemian-intellectual concern - much as Norman Lindsay's Redheap was to become ten years later when (at Brian's urging, as it happens) Lindsay allowed his ten-year-old manuscript novel to be published in England, only to have it banned for import by the Australian censors. Brian shared Olga's interest in Cabell, then, though no doubt mainly for its significance in the struggle against censorship, and his interest later manifested 
itself in the name he chose - Derek Cabell — for the hero of his novel Landtakers (1934).

The Pentons also shared other American literary interests. Both were great admirers of the 'Sage of Baltimore,' H.L. Mencken, an enthusiasm they shared with Norman Lindsay; they read (and later, in London, emulated) Mencken's literary magazine the American Mercury, ${ }^{18}$ and they endorsed his crusade against Mrs Grundy and 'Comstockery' — labels that Mencken, Cabell and others applied to the moral prudery they found in American cultural life, and which the Lindsay circle also saw on the march in Australia, in the escalating tendency to ban and censor books (like Lindsay's Redheap), and to persecute erotic art and sculpture (like Lindsay's). Penton's earlier attempt to set up a journal called 'The Pagan' - no doubt with support and assistance from Olga — as a radical alternative to Galmahra at the University of Queensland, may well have reflected these impulses.

There were differences, however, between the Pentons' American interests, and these too are of some significance. Brian's tastes ran more to the grim realism of Theodore Dreiser, Sinclair Lewis and the early John Dos Passos than to the archness and urbanity of Cabell, Hergesheimer and Van Vechten, and he was typically dismissive of Olga's predilection for them. His own later novels reflected these tastes, and even his unpublished attempt at a 'big city comedy' in the 1920s drew more upon the rambunctious humour of Huxley's Antic Hay and the depersonalised vertigo of Dos Passos' Manhattan Transfer than on the New York realists. ${ }^{19}$ He was even more contemptuous of her occasional 'lapses' towards the sentimental intensities of the English-Armenian novelist Michael Arlen, whose tragically self-destructive heroine Iris Storm (in The Green Hat, 1924) dominated the imaginations of sophisticated young Australian women probably more than any other fictional character of the 1920s.

Olga herself wrote at least two novels, neither of which was published. The second, probably written in the late 1930s, exists only in manuscript. It is set in the bush and is a family story based on her girlhood at 'Carraconna', somewhat in the style of 'G.B. Lancaster' (Edith Lyttleton), the Tasmanian-born author of pioneering novels like the best-selling Pageant (1933). Olga's earlier novel survives in a complete typescript. It was probably begun in Brisbane in the mid-1920s and finished in Sydney shortly before she left in 1929 to join Brian in London (her ticket having been paid for by former Prime Minister Billy Hughes, a friend of Penton's, in an impulse of unsolicited generosity following a chance meeting in a Sydney street). Her novel is called 'We Prometheans', and it is somewhat influenced — as the title suggests — by popular Nietzschean ideas, but is for the most part a self-consciously literary comedy of urban manners, very much in the style of Van Vechten novels like Parties and Firecrackers. ${ }^{20}$ It is densely and widely allusive to a range of classic authors including Catullus, Shakespeare, Sterne (who provides the epigraph), Dickens, Rabelais, Conrad and Dostoevsky, not to mention Wagner, Schopenhauer, Nietzsche, Freud and Einstein! It is also given to elaborate (at times fairly laborious) verbal wit; and it is occasionally quite salacious. Indeed, it features what must surely be the first condom in Australian 
literature - a detail no doubt suggested to Olga by her actual discovery of just such an object on the marital bed after returning from a week away: ${ }^{21}$

He coughed.

Near the leg of the chair where he must have dislodged it from the cushions lay a small, white, crumpled thing.

For a whole minute he merely stared at it. Then he walked across to the table and leaning his weight against the back of a chair stared at it from a different angle.

In the strong sunlight it glistened - a quality of human dejection in its flabby wrinkles, something about it symbolic of an illusion's titanic collapse. ${ }^{22}$

The passage, with its stylised and self-conscious naughtiness, epitomises the sexually emancipatory but politically circumscribed female bohemianism Olga found it possible to practise in Brisbane and Sydney in the 1920s.

During their time in Canberra in 1927-28, where Penton was making a reputation as a ferocious satirist of federal Parliament for the Sydney Morning Herald, Olga was widely rumoured, in both Parliament and the press gallery, to have written several of his columns. ${ }^{23}$ Certainly some of these columns, by contrast with those he wrote as the 'Sydney Spy' for the Telegraph some years later, are fiercely scholarly. They are also, at times, distinctly feline - a manner that Penton made very much his own as Editor in the 1940s, ${ }^{24}$ but which he may well have learned from Olga. Whether the rumour about the co-authorship of the Herald column was literally true or not, it is clear that from a very early point in their marriage, Olga had decided to seek her emancipation not as a New Woman, but as 'Mrs Penton'.

That moment was postponed by their four years in London (1929-33), where there was scope for Olga to assert and enjoy a more straightforward kind of independence than she had since her marriage. Brian, arriving some months ahead of Olga, had entertained Jack Lindsay (and enraged 'Inky' Stephensen) with his cheerfully priapic assaults — some of them successful — on Bloomsbury housemaids, pretty bus passengers, Fanfrolico typists, and probably Jack's unstable wife Elza. ${ }^{25}$ When Olga turned up, the Lindsays and Pentons moved into a house in Hampstead, with a small printing press in the basement, until the short-lived harmony of the household was destroyed by sexual tensions between Brian and Elza, and probably also between Jack and Olga, who - to Elza's great annoyance - had bonded closely over Jack's translations of Catullus and Ausonius. The Pentons then installed themselves in relative comfort in a large flat in Brunswick Square, partly on the strength of Penton's casual sub-editing for the Daily Express, but mainly on that of Olga's lucrative job teaching English and Latin at Pitman's Business College in Southampton Row, and later her royalties from a Latin primer that sold well. During this time, their circle of friends and occasional dinner guests expanded well beyond the Fanfrolico expatriates (some of whom resented the 'disloyalty') to include several of the younger British and émigré European writers, artists and 
academics. One of the last, a Romanian-Jewish economist named Jacques Kahane, became a close friend, a collaborator with Brian and a lover to Olga. ${ }^{26}$

Back in Sydney, though Olga deliberately chose 'home duties' over a teaching job, their lives increasingly separated out: Brian's into the hectic routines of daily journalism and weekend sailing (which Olga hated and avoided), hers into opera, books and ballet (which Brian hated and avoided). There were some friends in common - Godfrey ('Geof') and Merle ('Mick') Blunden, for example, with whom they shared a house in Sydney briefly, and whose place at Kurrajong they both used as a writing retreat in the mid-1930s (see Figure 4). But the emotional separation was cemented by Penton's two long-term, and not quite serial, extramarital relationships — 'mistresses' in the old terminology - one through the late 1930s and early 1940s, the other (with an overlap, unknown to either woman, of about a year) from 1944 until his death in 1951. Both relationships were matters of public knowledge in the newspaper world, and Olga herself certainly knew of them and tolerated them - her complaisance was regarded by some as an exemplary instance of female modernity, by others as a vestige of her earlier bohemianism. ${ }^{27}$ She rationalised her situation in those terms herself, and in that same spirit 'took a lover' more than once, always with Brian's knowledge and approval, and sometimes at his direct instigation, as in the relationship of social and sexual convenience she formed with his closest friend and ally at the Telegraph, Philip Wynter, which began a few years before his death and continued for a year or so after it. ${ }^{28}$

The later unpublished memoir by Olga, from which I quoted earlier, suggests that her apparent nonchalance may have masked a nagging sense of pain and betrayal, and her refusal ever to meet either 'mistress' probably signified rather more than a desire to avoid awkwardness. So thought the journalist Zélie Macleod, the second 'mistress', who was greatly moved when Olga invited her to visit Penton in the hospital a week before his death: she recognised the magnanimity of Olga's gesture and the effort it required. ${ }^{29}$

After Brian's death, Olga (now in her mid-fifties) sought work in publishing through her friendship with Norman Lindsay, but he could do little for her. Sir Frank Packer, her husband's former boss (whom she barely knew), offered her editing work in the growing Consolidated Press empire, first with the Shakespeare Head Press and then - her last job - with Golden Press, publisher of the Little Golden Books series for children, for which Consolidated Press had acquired the Australasian rights in $1950 .^{30}$ Packer may also have given her the direct financial assistance she needed to stay on for the rest of her life in the large house in Elizabeth Bay Road in which she had lived with Brian for ten years. ${ }^{31}$

Olga's last years, according to her niece, were by no means unhappy. She remained cheerful, sociable, sometimes flirtatious, and surprisingly youthful in appearance. She attended concerts, visited with friends and family, and practised her newfound Catholic faith with devotion and enthusiasm. She also wrote letters - many of them, in the early 1960s, to an American film production company which had taken out an option on Penton's Landtakers, and which she was trying to persuade to act upon it. Those negotiations came to nothing. The attempts she 


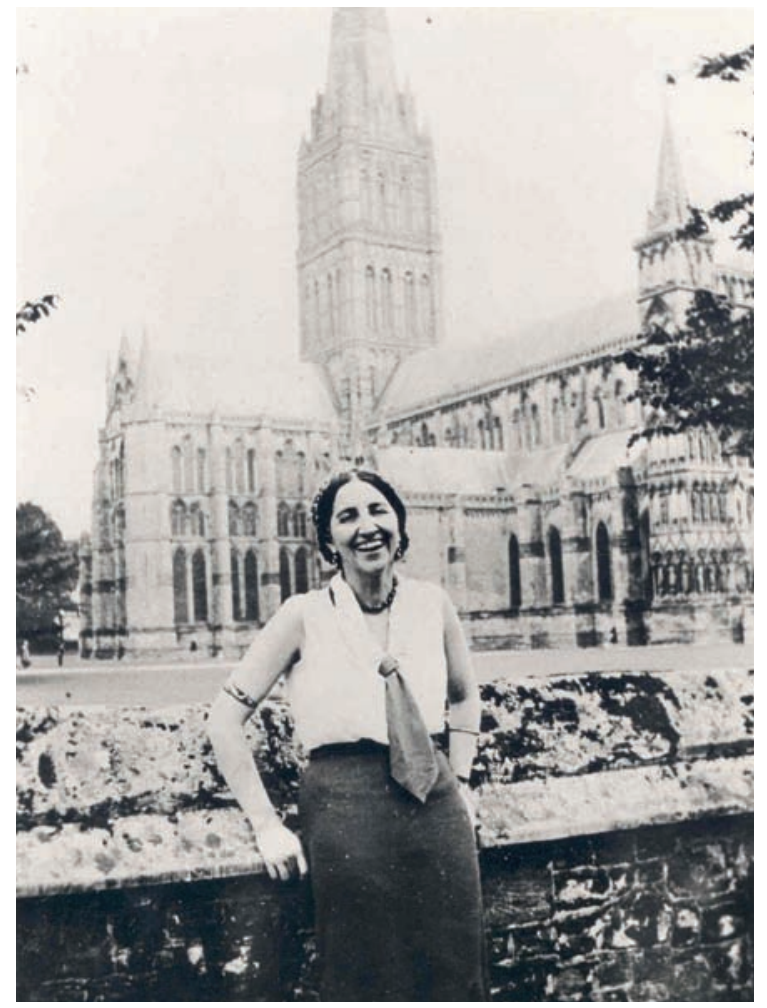

Figure 3: Olga at Salisbury Cathedral, 1932

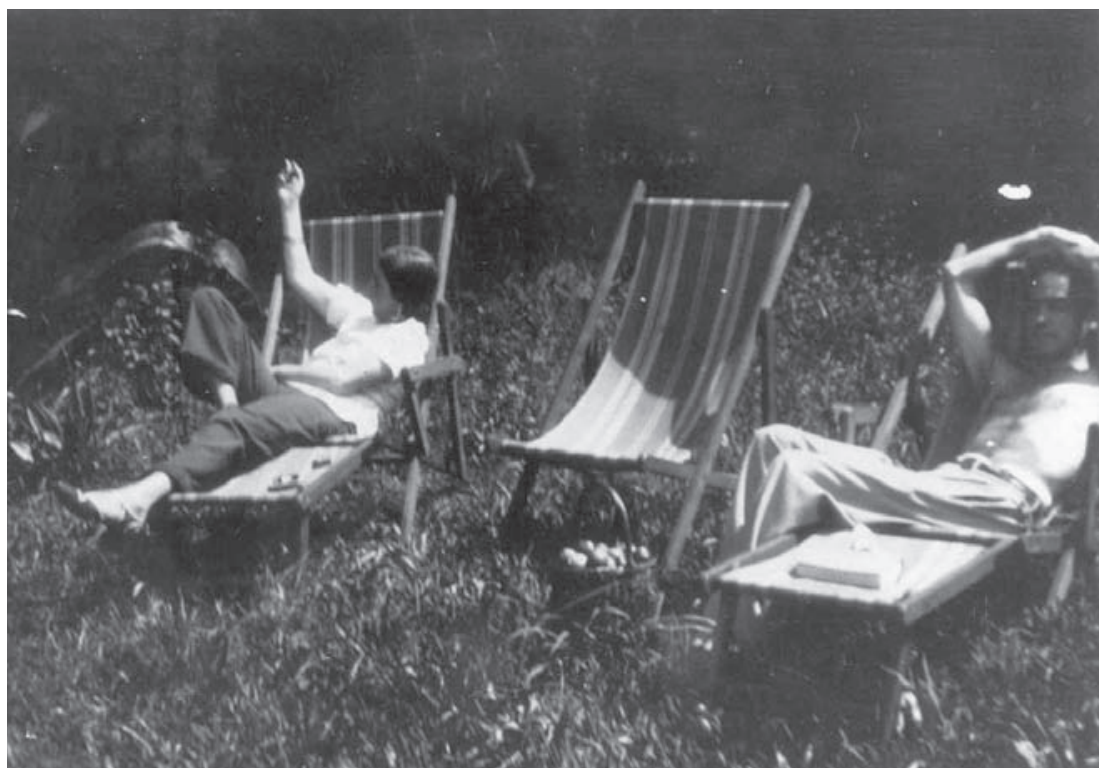

Figure 4: Olga and Brian Penton, Kurrajong 1936 


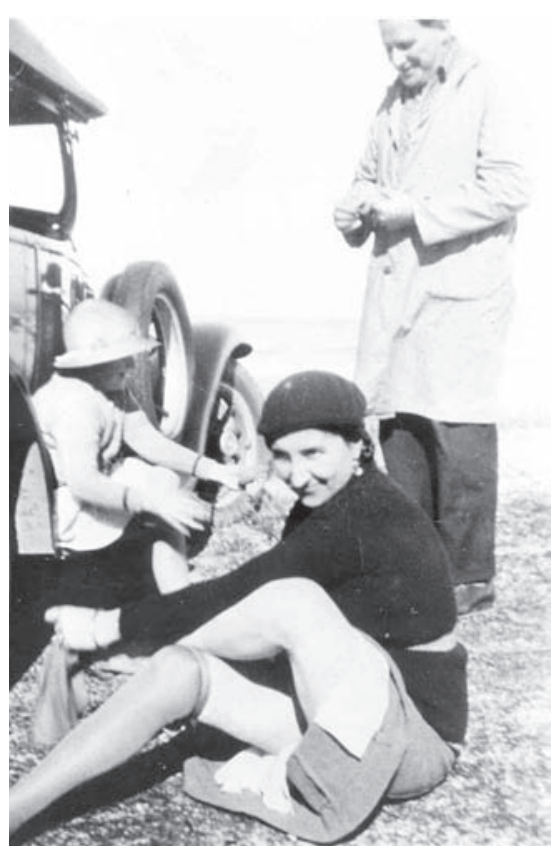

Figure 5: Olga (centre) with niece Enid Kyle (left) and brother-in-law Bert Kyle (right), c. 1938

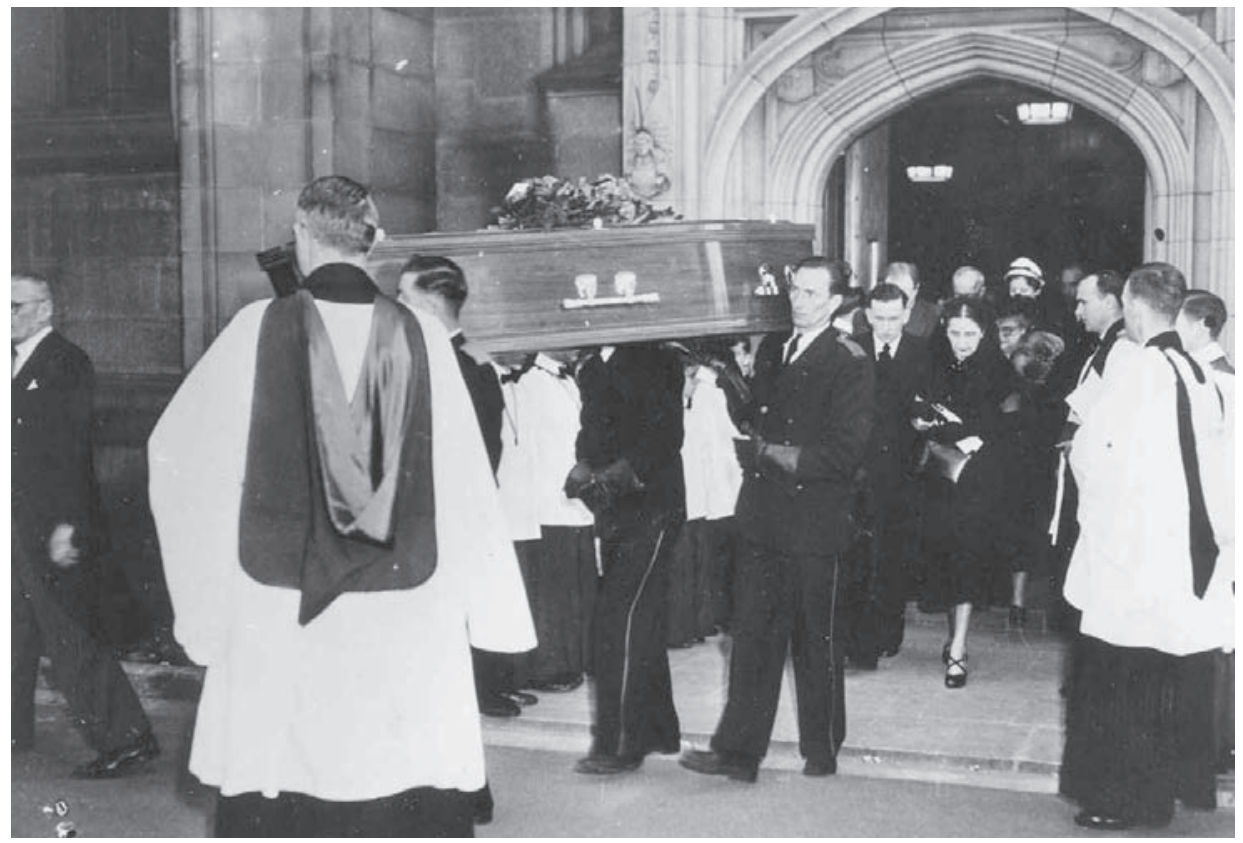

Figure 6: Funeral of Brian Penton, St Andrew's Cathedral, central Sydney, August 1951 (Olga with nephew Russell Moss behind the pall-bearers) 
made in the first ten years of her widowhood to write her husband's biography also came to nothing. In my book on Penton, published many years ago, I suggested (perhaps a little melodramatically) that this and other instances of unfinished Penton projects and missing Penton archives constituted the deliberate 'forgetting' of a figure too scandalous to be comfortably remembered. ${ }^{32}$

Whatever the truth of that thesis, a more modest psychological interpretation suggests itself with regard to the unfinished biography by Olga, and that is that the kind of searching and detailed recollection of the life she shared with Brian Penton presented her, inescapably, with the painful contradictions between her independent intellectual ambitions and achievements as a writer and teacher in Brisbane and London, and the two decades of compromise, rationalisation and partial self-delusion to which she had condemned herself in Sydney. This is not necessarily the judgment that anyone else should presume to pass upon her life, but it may be the one she felt she might have had to pass upon it herself had she continued with her extended retrospect.

\section{Notes}

1 My informants were Miss Kathleen Campbell-Brown (interviewed Brisbane 1986) and Mr Jack Kenny, a Courier colleague of Brian Penton's in the 1920s (interviewed Sydney, 1987).

2 Olga Penton MS, Brian Penton Papers, UQFL 230, Fryer Memorial Library, University of Queensland.

3 Galmahra, August 1924.

4 Penton Papers, UQFL 230. School records, New England Girls’ School, Armidale.

5 Penton Papers, UQFL 230.

6 Peter Kirkpatrick, The Seacoast of Bohemia: Literary Life in Sydney's Roaring Twenties (St Lucia: University of Queensland Press, 1993).

7 See William Hatherell, The Third Metropolis: Imagining Brisbane Through Art and Literature 1940-1970 (St Lucia: University of Queensland Press, 2007), 1-12.

8 The Muses' Magazine: A Monthly Review of the Musical, Artistic, Literary and Intellectual Life of Queensland (Hall of the Muses, George Street, Brisbane), 1 (1 November 1927): 1.

9 Galmahra, May 1924.

10 FL MS 5/317, University of Queensland.

11 Telephone interview with Professor A.K. Thomson, Brisbane, July 1987.

12 This paragraph draws on Jack Lindsay, Life Rarely Tells: An Autobiography in Three Volumes (Ringwood: Penguin, 1982), 127-35; and Craig Munro, Wild Man of Letters: The Story of P.R. Stephensen (Melbourne: Melbourne University Press, 1984), 12-28.

13 Jocelyn Rickards, The Painted Banquet (London: Weidenfeld \& Nicholson, 1987), 12.

14 The drawing was at one time in the possession of Mrs Joan Burke (formerly Joan Lindsay, Ray's widow), but its whereabouts are currently unknown. Interview with Joan Burke, 1987.

15 The source of this information is not Olga's extensive correspondence - all of which, unfortunately, has been lost, with the exception of some business correspondence in the 1960s — but rather interviews with her friends and relatives, and her husband's daily column, 'The Sydney Spy', in the Telegraph in 1933-35.

16 These figures are drawn from a privately compiled index of the Red Page which is currently in the author's possession. 
17 Information from the James Branch Cabell Library website, Virginia Commonwealth University, www.library.vcu.edu/jbc/speccoll/exhibit/cabell/jbcbio.html.

18 I refer to the London Aphrodite, the radical cultural magazine published by the Fanfrolico Press and edited by Jack Lindsay, P.R. Stephensen and later the Pentons. This was mainly billed as an alternative to the London Mercury, but its livelier American counterpart was also often mentioned, and Norman Lindsay, then and later, often referred to Brian Penton as potentially 'an Australian Mencken'.

19 This novel also exists only in typescript (Penton Papers, UQFL 230). Entitled 'Outrageous Fortune' (or in an earlier version, 'Waste Paper'), it circulated quite widely as a bound typescript in Sydney in the late 1920s, but was never published, though both Brian and Olga tried very hard to find outlets for their novels in London, through the literary agent Curtis Brown. Letters of Norman Lindsay, ed. R.G. Howarth and A.W. Barker (Sydney: Angus \& Robertson, 1979), 263. See also Philip Lindsay, I'd Live the Same Life Over (London: Hutchinson, 1943), 115.

20 Carl Van Vechten is probably best remembered today as the author of a popular and controversial early novel about the Harlem Renaissance, Nigger Heaven (1926). This aspect of Van Vechten's work does not seem to have interested Olga.

21 Telephone interview with Angus McLachlan, October 1991.

22 'We Prometheans', MS, 134ff. Penton Papers, UQFL 230.

23 A disgruntled member of the House, for example, read into Hansard in 1927 the charge that Penton's 'wife supplied the wit, while he put in the venom'. Commonwealth of Australia, Parliamentary Debates, vol. 116, First Session of the Tenth Parliament (Third Period), 26 October, 1927, 767.

24 For sympathetic and unsympathetic descriptions, respectively, of Penton's 'effeminate' and 'feline' qualities, see Donald Horne, Confessions of a New Boy (Ringwood: Penguin, 1985) and David McNicoll, Luck's a Fortune: An Autobiography (Melbourne: Sun Books, 1980).

25 Lindsay, Life Rarely Tells, 652-53.

26 Interview with Marion Miller, 1987.

27 Interview with Elizabeth Riddell, 1987.

28 Interview with Enid Parsons, 1987.

29 Interview with Zélie Macleod, 1988.

30 Bridget Griffen-Foley, The House of Packer: The Making of a Media Empire (Sydney: Allen \& Unwin, 1999), 153.

31 Interview with Zélie Macleod, 1987.

32 Patrick Buckridge, The Scandalous Penton: A Biography of Brian Penton (St Lucia: University of Queensland Press, 1994), viii. 